\title{
KETOKSIKAN AKUT ORAL ZAT PEWARNA MAKANAN DAUN JATI (Tectona grandis L. f.) PADA TIKUS WISTAR
}

\author{
[ORAL ACUTE TOXICITY OF FOOD DYING JATI LEAF (Tectona grandis L. f.) ON WISTAR RAT]
}

\author{
Candra Dwipayana Hamdin ${ }^{1)} *$ Dheni Cahyo $^{2)}$ dan Dandiko Galanova ${ }^{2)}$ \\ 1)Program Studi Farmasi Universitas Mataram \\ ${ }^{2)}$ Fakultas Farmasi Universitas Gadjah Mada \\ *email: candradwipayana@unram.ac.id
}

Diterima 15 September 2017/ Disetujui 16 November 2017

\begin{abstract}
Jati leaf becomes one of the alternative natural food coloring in some food producers. A research is needed to determine the potential of acute ketoxicity (LD50) and determine the clinical symptoms that arise also to see the groos patologi of organs resulting from single oral dosage of jati leaf extract. This research was conducted with complete randomized design using OECD 423 method. The test animal used was Wistar strain female rats. In this study, the test animals were divided into 2 groups, namely the control and treatment groups, each consisting of 3 test animals. Control group given $\mathrm{Na} C \mathrm{CMC} 0.5 \%$ and treatment group given jati leaf extract with a single dose of 2000 and $5000 \mathrm{mg} / \mathrm{kg} \mathrm{bw}$. Dosage starts from $2000 \mathrm{mg} / \mathrm{kg} \mathrm{bw}$, then increased to $5000 \mathrm{mg} / \mathrm{kg}$ bw in different rat. Observations were made for 14 days because single dose administration did not cause death. Test animals were sacrificed for gross observation of the vital organ pathologies (liver, kidney, heart, stomach, spleen, and small intestine). The results showed the potential toxicity (LD50) jati leaf extract using Wistar female rat test animal included in V category (not classified). The dosage of $2000 \mathrm{mg} / \mathrm{kg}$ bw did not show any change in behavior, the dosage of $5000 \mathrm{mg} / \mathrm{kg}$ bw gave clinical symptom on the central and somatomotor nerves in the form of increased aggressiveness and vocalization and gastrointestinal disturbances in the form of singultus in the test animals.
\end{abstract}

Keywords: Acute toxicity (LD50), gross pathology, histopathology, jati leaf extract (Tectona grandis L. f.), OECD 423.

\section{ABSTRAK}

Daun jati menjadi salah satu alternatif pewarna alami makanan pada sebagian produsen makanan. Perlu dilakukan penelitian untuk menentukan potensi ketoksikan akut (LD50) untuk mengetahui gejala-gejala klinik yang timbul dan melihat gambaran gross patologi organ akibat pemberian oral dosis tunggal ekstrak daun jati. Penelitian ini dilakukan dengan rancangan acak lengkap pola searah menggunakan metode OECD 423. Hewan uji yang digunakan adalah tikus betina galur Wistar. Pada penelitian ini, hewan uji dibagi menjadi 2 kelompok, yaitu kelompok kontrol dan perlakuan yang masingmasing terdiri dari 3 hewan uji. Kelompok kontrol dipejani Na CMC 0,5\% dan kelompok perlakuan dipejani ekstrak daun jati dengan dosis tunggal 2000 dan $5000 \mathrm{mg} / \mathrm{kg} \mathrm{BB}$. Dosis pemejanan dimulai dari $2000 \mathrm{mg} / \mathrm{kg} \mathrm{BB}$, kemudian dinaikkan menjadi $5000 \mathrm{mg} / \mathrm{kg}$ BB pada tikus yang berbeda. Pengamatan dilakukan selama 14 hari karena pemejanan dosis tunggal tidak menyebabkan kematian. Hewan uji dikorbankan untuk pengamatan gross patologi organ vitalnya (hati, ginjal, jantung, lambung, limpa, dan usus halus). Hasil penelitian menunjukkan potensi ketoksikan (LD50) ekstrak daun jati menggunakan hewan uji tikus betina galur Wistar termasuk dalam kategori V (tidak terklasifikasikan). Pemejanan dosis $2000 \mathrm{mg} / \mathrm{kg} \mathrm{BB}$ tidak menunjukkan perubahan tingkah laku, pada pemejanan dosis $5000 \mathrm{mg} / \mathrm{kg} \mathrm{BB}$ memberikan gejala klinis pada saraf pusat dan somatomotor berupa peningkatan agresifitas dan vokalisasi serta gangguan pada saluran cerna berupa singultus pada hewan uji.

Keywords: ekstrak daun jati (Tectona grandis L. f.), gross patologi, histopatologi, OECD 423, toksisitas akut (LD50)

\section{PENDAHULUAN}

Makanan tidak hanya sebagai sarana untuk pemenuhan kebutuhan gizi seseorang tetapi juga berguna untuk mempertahankan hidup manusia, selain itu jika ditangani dengan sungguh-sungguh akan menjadi sumber pendapatan masyarakat (Marwanti dkk., 2009). Untuk memperoleh hasil seperti yang dimaksud dibutuhkan berbagai bahan pendukung yang lazim untuk pangan yang disebut bahan tambahan makanan (BTM) atau zat aditif. Salah satu bahan tambahan makanan untuk menarik perhatian konsumen adalah zat pewarna (Fachruddin, 1998).

Zat pewarna makanan secara umum dibagi dalam tiga golongan, yaitu natural colours (zat warna alami), nature-identical 
colours (zat pewarna yang identik dengan zat pewarna alami), dan synthetic colours (zat pewarna sintetis). Sekarang ini lebih dari $90 \%$ zat pewarna yang digunakan oleh industri pangan adalah zat pewarna sintetis (Fachruddin, 1998).

Pewarna sintetik yaitu pewarna yang biasa digunakan untuk non pangan. Pewarna jenis ini berbahaya bagi kesehatan. (Mudjajanto, 2005). Beberapa pewarna yang masih banyak digunakan meskipun penggunaannya dilarang seperti Rhodamin B dan Metanil Yellow (Fachruddin, 1998).

Bahaya penggunaan pewarna sintetik pada makanan terutama industri pangan telah lama diketahui. Oleh karena itu, mulai dikembangkan pewarna makanan dengan bahan alami. Pewarna alami yang dikenal diantaranya adalah daun suji (warna hijau), daun jambu dan daun jati (warna oranye), serta kunyit (warna kuning) (Syah, 2005).

Berdasarkan komponen zat pewarnanya, Fachruddin (1998) membagi pewarna alami dibagi menjadi 5 jenis, salah satunya adalah antosianin yang menghasilkan warna oranye, merah, ungu, biru, dan coklat yang berasal dari daun jati. Daun jati telah sejak lama digunakan masyarakat secara tradisional sebagai pewarna makanan. Daun jati memiliki kandungan pigmen alamiah, salah satunya adalah golongan antosianin, yaitu pelargonidin (Erinda, 2011). Antosianin ini memiliki struktur dasar flavyllium ion yang dapat menjadi senyawa yang berbeda warna. Antosianin bisa dimodifikasi dengan merubah struktur senyawa pada posisi atom hidrogen, hidroksida, dan gugus metoksi (Anonim, 2011).

Seiring dengan berkembangnya penggunaan daun jati sebagai pewarna alami pada makanan, maka perlu dilakukan penelitian untuk mengetahui potensi ketoksikan (LD50) dan gejala-gejala klinik yang timbul secara cepat atau tertunda akibat pemejanan oral dosis tunggal ekstrak daun jati.

\section{BAHAN DAN METODE}

Bahan dan Alat

Bahan-bahan yang digunakan pada penelitian ini adalah:

a. Sampel uji ekstrak daun jati dengan komposisi $20 \%$ ekstrak daun jati muda dan $80 \%$ maltodekstrin.

b. Bahan-bahan lain yang digunakan adalah: akuades, Na CMC 0,5\%, formalin $10 \%$. c. Hewan uji tikus betina galur Wistar sebanyak 18 ekorAlat-alat yang digunakan pada penelitian:

Alat-alat gelas yang dipakai pada penelitian pada umumya seperti, gelas beker, labu takar, gelas ukur, cawan petri, dan pipet.

a. Alat-alat bedah yang lazim dipakai seperti, gunting, pinset, jarum, dan skapel.

b. Alat-alat lain seperti, spuit injeksi, neraca elektrik, timbangan tikus, spidol, pot organ, lup, mortir, dan stamper.

\section{Persiapan}

Bahan utama untuk penelitian ini adalah daun jati muda (bagian kuncup daun). Pelarut yang digunakan untuk ekstraksi adalah campuran etanol, aseton, dan air. Bahan pengisi yang digunakan dalam pembuatan serbuk zat warna adalah maltodekstrin (Karawuri, 2012).

Tahapan pembuatan ekstrak dimulai dari pengumpulan bahan baku utama yaitu daun jati muda, kemudian diblender, setelah itu hasil blender dikeringkan dengan oven selama \pm 15 menit. Daun jati yang telah diblender diekstraksi dengan labu leher tiga. Setelah diekstraksi dengan labu leher tiga, hasil dianalisis secara gravimetri kemudian dilakukan pengeringan dengan oven. Namun sebelum dilakukan pengeringan, terlebih dahulu ekstrak ditambahkan maltodekstrin. Campuran ekstrak dengan maltodekstrin menggunakan perbandingan 1:5. Sehingga komposisi ekstrak yang digunakan pada penelitian ini adalah $20 \%$ ektrak daun jati muda dan $80 \%$ maltodekstrin.

Larutan $\mathrm{Na}$ CMC 0,5\% digunakan sebagai suspending agent ekstrak daun jati. Dalam penelitian ini ekstrak dibuat suspensi dengan volume maksimal pemberian $3 \mathrm{~mL}$ untuk tikus yang berbobot 200 gram, karena berat badan hewan uji yang digunakan tidak ada yang melebihi 200 gram. Perhitungan tersebut berdasarkan pada aturan yang ditetapkan oleh OECD 423 bahwa pemberian maksimal volume sediaan suspensi sebesar 2 $\mathrm{mL} / 100$ gram berat badan hewan uji. Sediaan uji diberikan dalam bentuk suspensi dengan rute pemberian per oral.

Hewan uji yang digunakan adalah tikus betina galur Wistar, sehat, umur 2-3 bulan, berat badan 150-200 gram, dan dengan pakan berupa pelet. Hewan uji diperoleh dari Unit Pengembangan Hewan Percobaan (UPHPLPPT) Universitas Gadjah Mada Yogyakarta. 


\section{Rancangan Percobaan}

Penelitian ini merupakan penelitian eksperimental rancangan acak lengkap pola searah dengan variabel penelitian sebagai berikut:

1. Variabel bebas: dosis pemejanan ekstrak daun pada tikus betina galur wistar.

2. Variabel tergantung: potensi ketoksikan akut ekstrak daun jati, gejala-gejala klinik, dan gross patologi pada organ hati, ginjal, jantung, lambung, limpa, dan usus halus.

3. Variabel terkendali: jenis kelamin, galur, umur, jumlah makan, dan volume minum, berat badan jalur pemejanan sediaan uji, dan kondisi lingkungan.

\section{Analisis}

Data yang diperoleh pada penelitian ini meliputi data kualitatif dan kuantitatif. Data kualitatif meliputi pengamatan fisik gejala klinik, dan gross patologi hati, ginjal, usus halus, lambung, jantung, dan limpa. Sedangkan data kuantitatif meliputi purata kenaikan berat badan perhari (PKBP) hewan uji, purata berat organ hati, ginjal, usus halus, lambung, jantung, dan limpa serta purata berat pakan dan volume minum hewan uji. Purata kenaikan berat badan perhari diperoleh dari data penimbangan berat badan hewan uji. Selanjutnya purata kenaikan berat badan perhari, serta berat organ hati, ginjal, usus halus, lambung, jantung, dan limpa dianalisis secara statistik dengan SPSS 19.

Urutan uji yang dilakukan adalah uji distribusi normal dengan menggunakan informasi dari uji Kolmogorov-Smirnov. Dilanjutkan dengan uji homogenitas varian untuk mengetahui kesamaan varian data. Analisis parametrik yang digunakan adalah ANOVA untuk menganalisa apakah sampelsampel mempunyai rata-rata yang sama. Apabila dari uji ANOVA didapatkan rata-rata sampel tidak identik $(P<0,05)$ maka dilanjutkan dengan uji Post Hoc Test untuk mengetahui letak perbedaan nilai rata-rata pada sampel yang tidak identik.

\section{HASIL DAN PEMBAHASAN}

Sediaan uji diberikan lewat oral sebagai dosis tunggal, dengan terlebih dahulu ekstrak daun jati dilarutkan dalam Na CMC 0,5\% sebagai pelarutnya. Pada metode OECD 423, dosis yang dipejankan pada hewan uji sudah ditetapkan yaitu $5,50,300$, dan $2000 \mathrm{mg} / \mathrm{kg}$ BB (dosis tambahan $5000 \mathrm{mg} / \mathrm{kg}$ BB dapat dipertimbangkan).
Pada penelitian ini dosis yang diberikan pertama kali pada hewan uji sebesar 2000 $\mathrm{mg} / \mathrm{kg}$ BB. Hal ini dikarenakan penggunaannya di masyarakat sebagai zat pewarna alami pada makanan, sehingga diperkirakan ekstrak daun jati ini tidak toksik. Selain itu belum ada informasi mengenai ketoksikan akut dari ekstrak daun jati. Pengamatan hewan uji dilakukan sejak masa persiapan sebelum diberi perlakuan (masa penyesuaian hewan uji terhadap situasi dan kondisi pelaksanaan eksperimen) selama 1 minggu. Sediaan uji kemudian dipejankan pada hewan uji secara oral dengan dosis tunggal bagi kelompok hewan sediaan uji dan larutan Na CMC 0,5\% bagi kelompok kontrol negatif. Setelah mendapat perlakuan, dilakukan pengamatan secara intensif selama 4 jam kemudian pengamatan dilanjutkan selama 24 jam sesering mungkin.

Apabila pada kelompok perlakuan terdapat 2 atau 3 hewan uji mati, dilakukan penambahan kelompok perlakuan dengan penurunan dosis sampai dosis yang hanya memberikan 1 kematian hewan uji atau bahkan tidak ada kematian. Tetapi jika tidak ada hewan uji atau hanya 1 ekor hewan uji yang mati, maka dapat langsung ditetapkan LD50. Sebelum menetapkan LD50 perlu dilakukan pengulangan dosis pada kelompok tambahan dengan perlakuan yang sama seperti kelompok sebelumnya. Hewan uji tetap diamati selama 14 hari untuk melihat efek tertunda akibat pemejanan sediaan uji. Berat pakan dan volume minum tetap dikontrol, termasuk penimbangan berat badan tikus tiap 3 hari sekali (Anonim, 2001b).

Data yang diperoleh dalam penelitian uji toksisitas akut ini meliputi data kualitatif dan kuantitatif. Data kualitatif yang diperoleh berupa gejala klinik, hasil pengamatan organ secara gross patologi, wujud efek toksik serta spektrum efek toksik setelah pemejanan sediaan uji terhadap hewan uji selama 24 jam, terutama 4 jam setelah pemejanan sampai 14 hari setelahnya untuk melihat efek yang tertunda. Sedangkan data kuantitatif meliputi jumlah kematian hewan uji yang digunakan untuk menentukan nilai potensi ketoksikan akut (LD50), berat badan tiap 3 hari selama 14 hari dan berat organ dari hewan uji setelah hewan uji dikorbankan. Selain itu juga dilihat berat organ hewan uji setelah dibedah, berat pakan dan volume hewan uji. 


\section{Potensi Ketoksikan Akut (LD50)}

Dosis yang diberikan pada hewan uji dimulai dari dosis $2000 \mathrm{mg} / \mathrm{kg}$ BB dengan perhitungan volume pemberian maksimal $3 \mathrm{~mL}$ untuk tikus berbobot 200 gram. Pada dosis ini, tidak terdapat hewan uji yang mati, sehingga dilakukan pengulangan. Setelah pengulangan menghasilkan data yang sama maka dosis pun dinaikkan menjadi $5000 \mathrm{mg} / \mathrm{kg}$ BB dengan aturan volume pemberian yang sama. Pada dosis ini tidak ditemukan hewan uji yang mati sehingga dilakukan pengulangan dengan dosis yang sama. Pengulangan pun menunjukkan hasil yang sama. Sehingga tiap tingkat dosis dipejankan per oral pada tikus sebanyak 6 ekor tikus, yaitu 3 tikus pada pemberian pertama kemudian 3 ekor berikutnya adalah perulangan. Pada kelompok kontrol negatif, hewan uji diberikan $\mathrm{Na}$ CMC 0,5\% dengan volume $3 \mathrm{ml}$ untuk tikus 200 gram untuk mempermudah perhitungan pemberian.

Pengamatan dilakukan selama 24 jam setelah pemberian sediaan uji. Apabila ada hewan uji yang mati sebelum 24 jam maka hewan uji tersebut segera dibedah, diambil organ vitalnya seperti hati, ginjal, usus halus, jantung, lambung, paru-paru, dan limpa untuk diamati secara makroskopis. Pada kasus ini tikus yang dipejani sediaan uji tidak ada yang mengalami kematian pada dosis 2000 dan 500 $\mathrm{mg} / \mathrm{kgBB}$ pada 24 jam pertama baik pemberian pertama maupun pengulangan pada hewan yang berbeda hingga hari ke 14 penelitian. Sehingga pada hari ke 14 hewan uji dikorbankan untuk melihat efek tertunda yang mungkin muncul. Pengamatan secara mikroskopis dilakukan pada 7 organ vitalnya yaitu hati, ginjal, usus halus, jantung, lambung, limpa, dan paru.

Jumlah kematian hewan uji pada masing-masing kelompok kontrol maupun kelompok dosis setelah pemberian ekstrak daun jati dapat dilihat pada Tabel 1.

Tabel 1. Jumlah Kematian Hewan Uji pada Masing-masing Kelompok Kontrol dan Kelompok Dosis Setelah Pemberian Ekstrak Daun Jati (Tectona grandis L. f.) secara Oral Dosis Tunggal

\begin{tabular}{lcc}
\hline \multicolumn{1}{c}{ Kelompok } & $\begin{array}{c}\text { Langkah I (3 } \\
\text { ekor) }\end{array}$ & $\begin{array}{c}\text { Langkah II (3 } \\
\text { ekor) }\end{array}$ \\
\cline { 2 - 3 } & $\begin{array}{c}\boldsymbol{\Sigma} \text { hewan uji } \\
\text { mati }\end{array}$ & $\begin{array}{c}\boldsymbol{\Sigma} \text { hewan uji } \\
\text { mati }\end{array}$ \\
\hline $\begin{array}{l}\text { Kontrol Na CMC } \\
0,5 \%\end{array}$ & 0 & 0 \\
\hline $\begin{array}{l}\text { Dosis } 2000 \mathrm{mg} / \mathrm{kg} \\
\text { BB }\end{array}$ & 0 & 0 \\
\hline $\begin{array}{l}\text { Dosis } 5000 \mathrm{mg} / \mathrm{kg} \\
\text { BB }\end{array}$ & 0 & 0 \\
\hline
\end{tabular}

Kategori yang didapatkan dari Globally Harmonized Classification System (GHS) pada Pedoman OECD 423 menunjukkan bahwa sediaan uji ekstrak daun jati termasuk kategori V (tidak terklasifikasikan). Sehingga LD50 yang dapat disimpulkan berupa suatu perkiraan (cut off) yaitu tidak terklasifikasikan pada tikus betina galur Wistar.

\section{Pengamatan Gejala Toksik}

Gejala toksik yang diamati meliputi perubahan perilaku, gerakan, kereaktifan terhadap rangsang, reflek serebral dan spinal, ukuran pupil, sekresi, pernafasan, palpitasi kardiak, kulit, rambut, dan kondisi umum.

Hasil pengamatan kualitatif gejalagejala toksik pada hewan uji setelah pemberian sediaan ekstrak daun jati memperlihatkan adanya gejala-gejala toksik yang cukup jelas pada dosis $5000 \mathrm{mg} / \mathrm{kg} \mathrm{BB}$ tahap I dan II. Gejala yang terjadi pada kelompok dosis $2000 \mathrm{mg} / \mathrm{kg}$ BB tahap I dan II hampir sama dengan yang terjadi pada kelompok kontrol yaitu tidak ada perilaku hewan uji yang menunjukkan gejala-gejala klinik yang berarti. Gejala-gejala klinik sebagai tanda ketoksikan yang muncul selama 24 jam dapat dilihat pada Tabel 2.

Tabel 2. Hasil Pengamatan Kualitatif Gejala Toksik pada Tikus Jantan Galur Wistar 24 Jam Pertama Hingga Sesaat Sebelum Dikorbankan Setelah Pemberian Ekstrak Daun Jati (Tectona grandis L. f.) Secara Oral Dosis Tunggal

\begin{tabular}{|c|c|c|}
\hline $\mathbf{K} \mathbf{I}$ & Kd & Gejala toksik \\
\hline \multirow{3}{*}{$\mathrm{K}$} & $\mathrm{a}$ & Tidak ada gejala \\
\hline & $\mathrm{b}$ & Tidak ada gejala \\
\hline & C & Tidak ada gejala \\
\hline \multirow{3}{*}{1} & $a$ & Tidak ada gejala \\
\hline & $\mathrm{b}$ & Tidak ada gejala \\
\hline & C & Tidak ada gejala \\
\hline \multirow{3}{*}{$1^{*}$} & $\mathrm{a}$ & Tidak ada gejala \\
\hline & $\mathrm{b}$ & Tidak ada gejala \\
\hline & C & Tidak ada gejala \\
\hline \multirow{3}{*}{2} & a & $\begin{array}{l}\text { Vokalisasi luar biasa. Tikus tetap hidup } 14 \\
\text { hari hingga waktu dikorbankan. }\end{array}$ \\
\hline & b & $\begin{array}{l}\text { Vokalisasi luar biasa. Tikus tetap hidup } 14 \\
\text { hari hingga waktu dikorbankan. }\end{array}$ \\
\hline & C & $\begin{array}{l}\text { Mengalami singultus (cegukan) beberapa } \\
\text { kali pada } 40 \text { menit awal. Vokalisasi luar } \\
\text { biasa. Tikus tetap hidup } 14 \text { hari hingga } \\
\text { waktu dikorbankan. }\end{array}$ \\
\hline \multirow{3}{*}{ 2* } & a & $\begin{array}{l}\text { Vokalisasi luar biasa. Tikus tetap hidup } 14 \\
\text { hari hingga waktu dikorbankan. }\end{array}$ \\
\hline & b & $\begin{array}{l}\text { Vokalisasi luar biasa. Tikus tetap hidup } 14 \\
\text { hari hingga waktu dikorbankan. }\end{array}$ \\
\hline & C & $\begin{array}{l}\text { Sedikit agresif. Vokalisasi luar biasa. Tikus } \\
\text { tetap hidup } 14 \text { hari hingga waktu } \\
\text { dikorbankan. }\end{array}$ \\
\hline
\end{tabular}


Keterangan:

(KI) kelompok

(Kd) kode hewan

(K) Kontrol Na CMC 0,5\%

(1) Dosis $2000 \mathrm{mg} / \mathrm{kgBB}$

(2) Dosis $5000 \mathrm{mg} / \mathrm{kgBB}$

(*) dosis pengulangan

Pengamatan dilanjutkan hingga 14 hari pada dosis $2000 \mathrm{mg} / \mathrm{kg}$ BB dan dosis 5000 $\mathrm{mg} / \mathrm{kg} \mathrm{BB}$, termasuk kelompok pengulangan dan kelompok kontrol. Hasil pengamatan kualitatif gejala toksik selama 14 hari terlihat dalam Tabel 3.

Tabel 3. Hasil Pengamatan Kualitatif Gejala Toksik Ekstrak Daun Jati (Tectona grandis L. $f$.) Secara Oral Dosis Tunggal Selama Pengamatan 14 Hari pada Tikus Betina Galur Wistar

\begin{tabular}{|c|c|c|c|c|c|c|c|c|c|c|c|c|c|c|c|}
\hline \multirow[b]{2}{*}{$\begin{array}{l}\mathbf{K} \\
\mathbf{I}\end{array}$} & \multirow[b]{2}{*}{$\begin{array}{l}\mathbf{K} \\
\mathbf{d}\end{array}$} & \multicolumn{14}{|c|}{ Gejala toksik hari ke- } \\
\hline & & 1 & 2 & 3 & 4 & 5 & 6 & 7 & 8 & 9 & $\begin{array}{l}1 \\
0\end{array}$ & $\begin{array}{l}1 \\
1\end{array}$ & $\begin{array}{l}\mathbf{1} \\
\mathbf{2}\end{array}$ & $\begin{array}{l}1 \\
\mathbf{3}\end{array}$ & $\begin{array}{l}1 \\
4\end{array}$ \\
\hline \multirow[t]{3}{*}{ K } & a & - & - & - & - & - & - & - & - & - & - & - & - & - & - \\
\hline & $\mathrm{b}$ & - & - & - & - & - & - & - & - & - & - & - & - & - & - \\
\hline & $\mathrm{C}$ & - & - & - & - & - & - & - & - & - & - & - & - & - & - \\
\hline \multirow[t]{3}{*}{1} & $a$ & - & - & - & - & - & - & - & - & - & - & - & - & - & - \\
\hline & $b$ & - & - & - & - & - & - & - & - & - & - & - & - & - & - \\
\hline & $C$ & - & - & - & - & - & - & - & - & - & - & - & - & - & - \\
\hline \multirow{3}{*}{$\begin{array}{l}1 \\
*\end{array}$} & $a$ & - & - & - & - & - & - & - & - & - & - & - & - & - & - \\
\hline & $b$ & - & - & - & - & - & - & - & - & - & - & - & - & - & - \\
\hline & C & - & - & - & - & - & - & - & - & - & - & - & - & - & - \\
\hline \multirow[t]{3}{*}{2} & a & + & - & - & - & - & - & - & - & - & - & - & - & - & - \\
\hline & b & + & - & - & - & - & - & - & - & - & - & - & - & - & - \\
\hline & C & $\wedge$ & - & - & - & - & - & - & - & - & - & - & - & - & - \\
\hline \multirow{3}{*}{$\begin{array}{l}2 \\
*\end{array}$} & $a$ & + & - & - & - & - & - & - & - & - & - & - & - & - & - \\
\hline & b & + & - & - & - & - & - & - & - & - & - & - & - & - & - \\
\hline & C & $\begin{array}{l}+ \\
>\end{array}$ & - & - & - & - & - & - & - & - & - & - & - & - & - \\
\hline \multicolumn{5}{|c|}{ Keterangan: } & \multicolumn{11}{|c|}{$\begin{array}{l}\text { (-) tidak menunjukkan gejala toksik } \\
(*) \text { dosis pengulangan } \\
(+) \text { vokalisasi luar biasa } \\
(\wedge) \text { singultus (cegukan) } \\
(>) \text { agresif } \\
(\mathrm{KI}) \text { kelompok } \\
(\mathrm{Kd}) \text { kode hewan } \\
(\mathrm{K}) \text { Kontrol Na } \mathrm{CMC} \mathrm{0,5 \%} \\
(1) \text { Dosis } 2000 \mathrm{mg} / \mathrm{kgBB} \\
(2) \text { Dosis } 5000 \mathrm{mg} / \mathrm{kgBB} \\
(*) \text { dosis pengulangan }\end{array}$} \\
\hline
\end{tabular}

Dari Tabel 2 reaksi yang tampak pada hari pertama tersebut tidak tampak lagi pada hari berikutnya sampai hari ke-14. Hal ini menunjukkan bahwa gejala yang muncul pada kelompok perlakuan bersifat reversible pada gejala klinik. Dari Tabel 3 dapat disimpulkan bahwa setelah pemberian sediaan uji dihentikan tidak muncul efek toksik yang tertunda.

\section{Kondisi Umum}

Pengamatan terhadap kondisi umum hewan uji meliputi perubahan berat badan, kematian, berat pakan, dan volume minum hewan uji. Pada penelitian ketoksikan akut data perubahan berat badan hewan uji merupakan salah satu parameter yang digunakan untuk mengevaluasi kondisi kesehatan secara umum dari hewan uji. Pengamatan ini dapat digunakan untuk mempelajari kemungkinan mekanisme efek toksik akibat pemberian sediaan uji.

Penimbangan berat badan hewan uji dilakukan pada hari ke-0, yaitu sebelum pemejanan sediaan uji, kemudian penimbangan dilakukan lagi sebelum hewan uji dikorbankan. Hewan uji dipelihara sampai 14 hari dan dilakukan penimbangan berat badan tiap 3 hari sekali untuk menghindari terjadinya stres.

Tabel IV. Hasil Purata Kenaikan Berat Badan per Hari (PKBP $\pm \mathrm{SD})$ (g/hari) Tikus Betina Galur Wistar Selama 14 Hari Setelah Pemberian Ekstrak Daun Jati (Tectona grandis L. f.) Secara Oral Dosis Tunggal

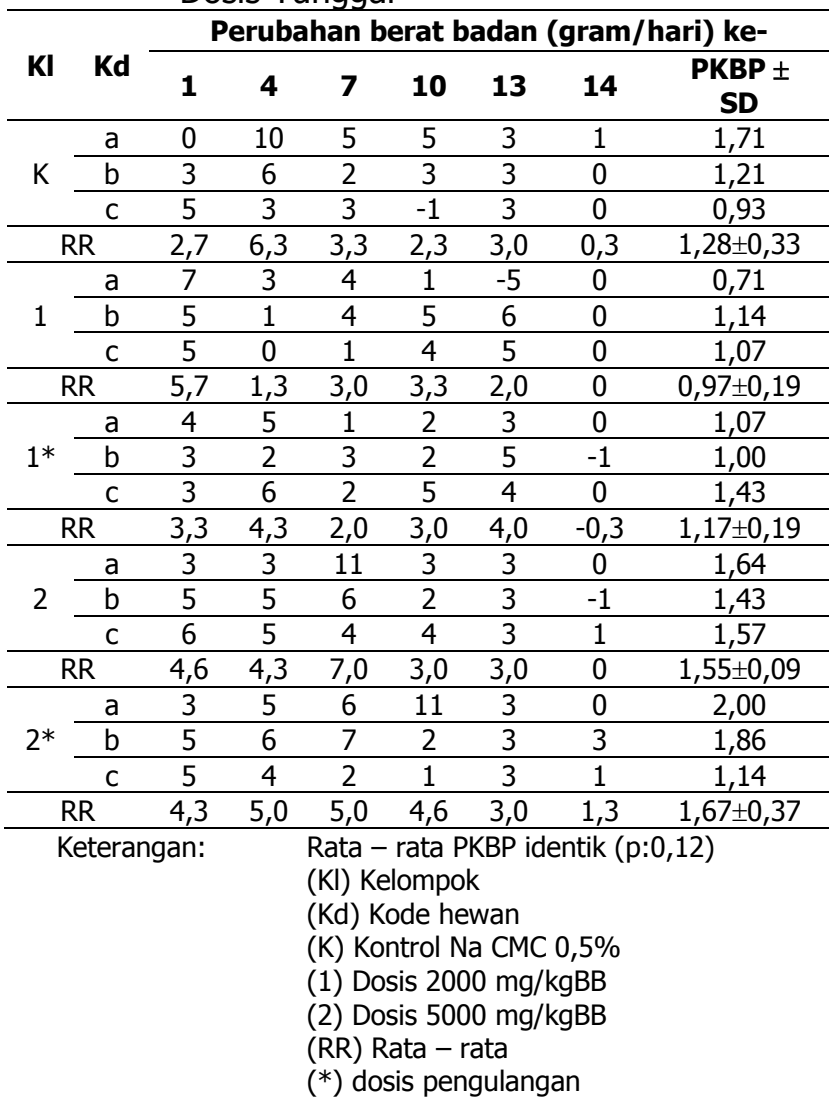

Pengamatan terhadap pengaruh pemberian ekstrak daun jati secara oral dosis tunggal dilakukan selama 14 hari. Hal ini dilakukan untuk melihat efek tertunda 
ketoksikan akut ekstrak daun jati. Selain itu untuk melihat hubungan antara perkembangan berat badan hewan uji dievaluasi menggunakan parameter purata kenaikan berat badan perhari (PKBP) dengan efek toksik yang muncul. Digunakan PKBP karena pada awal penelitian berat badan hewan uji untuk setiap kelompok tidak sama. Selain itu, dengan menggunakan perhitungan PKBP akan lebih memudahkan pengamatan perubahan berat badan hewan uji dari setiap kelompok. Data purata kenaikan berat badan perhari (PKBP) hewan uji selama 14 hari dapat dilihat pada Tabel 4.

Analisis terhadap perbedaan purata kenaikan berat badan perhari (PKBP) hewan uji antara kelompok kontrol dengan kelompok perlakuan tidak berbeda signifikan berdasarkan hasil uji ANOVA.

Tabel 5. Data Berat Pakan dan Volume Minum Hewan Uji

\begin{tabular}{|c|c|c|c|c|}
\hline \multirow{2}{*}{ KI } & \multirow{2}{*}{ Parameter } & \multicolumn{2}{|c|}{ Minggu ke- } & \multirow{2}{*}{ Rata-rata } \\
\hline & & I & II & \\
\hline \multirow[t]{2}{*}{ K } & Pakan (g) & 7,50 & 7,50 & $1,07 \mathrm{~g} /$ hari \\
\hline & Minum (L) & 1,25 & 1,35 & $0,19 \mathrm{~L} /$ hari \\
\hline \multirow[t]{2}{*}{1} & Pakan (g) & 8,00 & 9,00 & $1,21 \mathrm{~g} /$ hari \\
\hline & Minum (L) & 1,25 & 1,35 & $0,19 \mathrm{~L} / \mathrm{h}$ ari \\
\hline \multirow[t]{2}{*}{$1^{*}$} & Pakan (g) & 8,00 & 8,00 & $1,14 \mathrm{~g} /$ hari \\
\hline & Minum (L) & 1,25 & 1,25 & $0,17 \mathrm{~L} /$ hari \\
\hline \multirow[t]{2}{*}{2} & Pakan (g) & 9,75 & 8,75 & $1,32 \mathrm{~g} /$ hari \\
\hline & Minum (L) & 1,35 & 1,25 & $0,19 \mathrm{~L} / \mathrm{hari}$ \\
\hline \multirow[t]{2}{*}{ 2* } & Pakan (g) & 9,00 & 8,25 & $1,23 \mathrm{~g} /$ hari \\
\hline & Minum (L) & 1,25 & 1,20 & $0,18 \mathrm{~L} /$ hari \\
\hline eteran & $\begin{array}{ll}\text { yan : } & \mathrm{D} \\
& \mathrm{R} \\
& \mathrm{R} \\
& \mathrm{R} \\
& (\mathrm{K} \\
& (\mathrm{K} \\
& (1 \\
& (2\end{array}$ & \multicolumn{3}{|c|}{$\begin{array}{l}\text { Dosis pengulangan }(*) \\
\text { Rata-rata pakan identik (sig. 0,23) } \\
\text { Rata-rata minum identik (sig. 0,10) } \\
\text { (KI) Kelompok } \\
\text { (K) Kontrol Na CMC 0,5\% } \\
\text { (1) Dosis } 2000 \mathrm{mg} / \mathrm{kgBB} \\
\text { (2) Dosis } 5000 \mathrm{mg} / \mathrm{kgBB}\end{array}$} \\
\hline
\end{tabular}

Data lain yang dianalisis selain PKBP adalah data berat pakan dan volume minum dari hewan uji. Penimbangan berat pakan dan pengukuran volume minum dilakukan setiap 7 hari sekali. Hal ini dilakukan untuk melihat kaitan antara peningkatan berat badan dengan asupan jumlah pakan dan minum hewan uji. Perubahan berat badan yang terjadi pada hewan uji bisa mengindikasikan terjadinya gangguan atau patologi pada hewan uji. Namun dalam penelitian ini tidak ditemukan pebedaan bermakna pada PKBP. Sehingga dapat dikatakan tidak terjadi patologi yang berarti pada hewan uji. Data berat pakan dan volume minum hewan uji dapat dilihat pada Tabel 5.

Dari analisis SPSS didapatkan nilai probabilitas normalitas, varian, dan hasil
ANOVA diatas 0,05 . Sehingga dapat dikatakan berat pakan dan volume minum tiap kelompok tidak berbeda signifikan dengan kata lain ratarata berat pakan dan volume minum hewan uji semua kelompok adalah identik.

\section{Pemeriksaan gross patologi}

Pemeriksaan makroskopis dikenal juga dengan gross patologi. Pemeriksaan gross patologi menggunakan lup atau kaca pembesar, hasil gross patologi tidak memperlihatkan perbedaan secara kasat mata antara kontrol dengan perlakuan.

Pengamatan makroskopis yang dilakukan terhadap organ vital hewan uji dengan cara mengamati organ hewan uji dibawah lup/kaca pembesar dilengkapi dengan penerangan yang cukup. Hasil pengamatan pada kelompok kontrol $\mathrm{Na}$ CMC 0,5\% tidak menunjukkan adanya kerusakan secara kasat mata. Hal yang sama juga terjadi pada kelompok perlakuan dosis $2000 \mathrm{mg} / \mathrm{kg}$ BB dan dosis $5000 \mathrm{mg} / \mathrm{kg}$ BB juga tidak menunjukkan adanya kerusakan pada organ hewan uji. Pengamatan makroskopis pada semua kelompok perlakuan selama 14 hari untuk melihat efek yang tertunda tidak menunjukkan adanya kerusakan. Dari hasil pengamatan makroskopis ini masih belum dapat disimpulkan pengaruh sediaan uji terhadap hewan uji karena perlu dilihat hasil pemeriksaan histopatologinya.

Tabel VI. Berat Rata-rata Organ ( $g)(x \pm S D)$ Tikus Betina Galur Wistar, 14 Hari Setelah Pemberian Ekstrak Daun Jati (Tectona grandis L. f.) Secara Oral Dosis Tunggal

\begin{tabular}{|c|c|c|c|c|c|}
\hline 0 & $\mathbf{K}$ & 1 & 1* & 2 & 2* \\
\hline \multirow{2}{*}{ ] } & 0,69 & 0,73 & 0,73 & 0,68 & 0,71 \\
\hline & $\pm 0,04$ & $\pm 0,05$ & $\pm 0,05$ & $\pm 0,04$ & $\pm 0,05$ \\
\hline \multirow{2}{*}{$P$} & 1,86 & 2,18 & 2,00 & 2,20 & 1,99 \\
\hline & $\pm 0,15$ & $\pm 0,34$ & $\pm 0,14$ & $\pm 0,34$ & $\pm 0,28$ \\
\hline \multirow{2}{*}{$\mathrm{H}$} & 6,74 & 6,87 & 8,00 & 7,34 & 7,10 \\
\hline & \pm 0.10 & $\pm 0,96$ & $\pm 0,46$ & $\pm 0,09$ & $\pm 1,17$ \\
\hline \multirow{2}{*}{ G } & 1,47 & 1,42 & 1,43 & 1,41 & 1,54 \\
\hline & $\pm 0,03$ & $\pm 0,08$ & $\pm 0,03$ & $\pm 0,05$ & $\pm 0,18$ \\
\hline \multirow{2}{*}{$\mathrm{Li}$} & 0,64 & 0,57 & 0,58 & 0,67 & 0,73 \\
\hline & $\pm 0,03$ & $\pm 0,04$ & $\pm 0,08$ & $\pm 0,05$ & $\pm 0,07$ \\
\hline \multirow{2}{*}{ La } & 1,77 & 1,69 & 1,72 & 1,60 & 0,74 \\
\hline & $\pm 0,10$ & $\pm 0,07$ & $\pm 0,05$ & $\pm 0,05$ & $\pm 0,07$ \\
\hline \multicolumn{2}{|c|}{ Keterangan: } & $\begin{array}{l}(*) \mathrm{d} \\
\text { Rata- } \\
(\mathrm{K}) \mathrm{K} \\
(1) \mathrm{D}\end{array}$ & $2000 \mathrm{n}$ & $\begin{array}{l}\text { an } \\
\text { identic } \\
0,5 \% \\
\text { gBB }\end{array}$ & \\
\hline
\end{tabular}




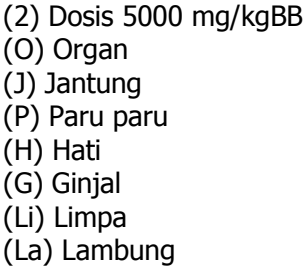

Selain itu dilakukan penimbangan organ yang bertujuan untuk mengetahui apakah pemberian sediaan uji dapat mempengaruhi organ vital. Penimbangan dilakukan sesaat setelah hewan uji dikorbankan. Hasil penimbangan dapat dibandingkan dengan hasil pemeriksaan histopatologinya. Apabila organ hewan uji mengalami peradangan, kemungkinan terjadi penambahan berat organ. Namun apabila hasil pemeriksaan histopatologi normal maka penambahan berat organ kemungkinan akibat faktor dari diri hewan uji tersebut. Hasil penimbangan organ hewan uji tersaji dalam tabel VI.

Analisa dengan SPSS 19 uji KolmogorovSemirnov didapatkan hasil semua sampel terdistribusi normal dan Test of Homogenitas of Varian mendapatkan hasil yang homogen pada semua varian. Sehingga dapat dikatakan rata-rata berat organ tidak berbeda signifikan antar kelompok, baik kontrol maupun perlakuan.

\section{KESIMPULAN}

1. Berdasarkan kategori yang didapatkan dari Globally Harmonized Classification System (GHS) pada Pedoman OECD 423, potensi ketoksikan (LD50) ekstrak daun jati yang diberikan secara oral dosis tunggal pada tikus betina galur Wistar termasuk kategori $\mathrm{V}$ (cut off tidak terklasifikasikan)

2. Pengamatan secara gross patologi terhadap pemberian ekstrak daun jati dosis 2000 dan $5000 \mathrm{mg} / \mathrm{kg}$ BB tidak memberikan efek toksik pada organ hati, ginjal, usus halus, jantung, lambung, limpa, dan paru.

\section{DAFTAR PUSTAKA}

Anonim ${ }^{\mathrm{a}}$, 2001, OECD Guideline for Testing of Chemicals, Acute Oral Toxicity-Acute Toxic Class Method No.423, OECD, Paris.

Anonim ${ }^{b}$ 2011, Anthocyanins and Anthocyanidins, http://www.foodinfo.net/uk/colour/anthocyanin.htm, [diakses tanggal 1 Mei 2017]

Fachruddin L. 1998, Memilih dan Memanfaatkan Bahan Tambahan Makanan, 1, 34-46, Trubus Agriwidya, Ungaran.

Karawuri T. 2012, Ekstraksi Senyawa Flavon dari Daun Jati (Tectona grandis Linn f.) sebagai Alternatif Zat Warna Alami, [Laporan Penelitian]. Yogyakarta: Laboratorium Proses Pemisahan MIPA UGM.

Marwanti, Prihastuti E, Palupi S. 2009, Pengembangan Mutu Produk Makanan Kudapan Melalui Diversifikasi Pengolahan Untuk Meningkatkan Pendapatan Produsen, Laporan Hasil Pelaksanaan PPM, Pusat Pengembangan Pangan Yogyakarta, Yogyakarta.

Mudjadjanto SE. 2005, Tahu, Makanan Favorit yang Perlu Diwaspadai, Arsip KOMPAS, Jakarta.

Syah D. 2005, Manfaat dan Bahaya Bahan Tambahan Makanan, Skripsi, Institut Pertanian Bogor, Bogor. 